\title{
CONTROL OF SOFT REDUCTION OF CONTINUOUS SLAB CASTING WITH A THERMAL MODEL
}

\author{
KONTROLA MEHKE REDUKCIJE PRI KONTINUIRNEM LITJU \\ SLABOV S TERMIČNIM MODELOM
}

\author{
Josef Stetina, Pavel Ramik, Jaroslav Katolicky \\ Brno University of Technology, Technicka 2, 61669 Brno, Czech Republic \\ stetina@fme.vutbr.cz \\ Prejem rokopisa - received: 2014-08-09; sprejem za objavo - accepted for publication: 2014-10-17
}

doi:10.17222/mit.2014.189

\begin{abstract}
The internal quality of cast steel slabs during the radial continuous casting is significantly affected by the setting of support rollers. During the passes through the support rolls the steel cools from $1400{ }^{\circ} \mathrm{C}$ to $600{ }^{\circ} \mathrm{C}$, therefore the shrinkage of the material must be controlled with the setting of the reduction profile. The setting of the reduction profile with fixed rollers is a compromise used for all the cast steel. During the continuous casting the wear of the rolls occurs and this must also be considered when setting the profile with rollers. A 3D thermal model is used for the optimum setting. As the reduction setting cannot be optimized for older casters, internal defects are often present. New machines for continuous casting of steel are fitted with soft reduction, i.e., the system for controlling the roller position and setting the reduction profile for any type of steel. The control system is connected on-line with the 3D thermal model.

Keywords: concast slab, numerical models, contraction, soft reduction
\end{abstract}

Notranja kakovost ulitih jeklenih slabov pri radialnem kontinuirnem litju je odvisna od nastavitev podpornih valjev. Ko jeklo prehaja preko podpornih valjev, se ohlaja iz $1400{ }^{\circ} \mathrm{C}$ na $600{ }^{\circ} \mathrm{C}$. Pri tem nastaja krčenje materiala, kar je treba upoštevati pri nastavitvi profila. Nastavitev profila redukcije $\mathrm{z}$ valji je kompromis za vse ulito jeklo. Med kontinuirnim litjem nastaja tudi obraba valjev, ki jo je treba upoštevati pri nastavitvi profila z valji. Za optimalno nastavitev podpornih valjev je uporabljen 3D termični model. Nastavitve redukcije ni mogoče optimirati pri starih livnih napravah, zato so pogoste notranje napake. Nove naprave za kontinuirno litje jekla so opremljene $\mathrm{z}$ mehko redukcijo, to je s sistemom upravljanja kontrole pozicije valjev, ki omogoča nastavitev profila redukcije za vsako jeklo. Ta sistem kontrole je on-line povezan s 3D termičnim modelom.

Ključne besede: concast slab, numerični modeli, krčenje, mehka redukcija

\section{INTRODUCTION}

Materials with high utility parameters are increasingly in demand and the traditional production is being replaced with higher-quality steels. More and more sophisticated aggregates using more sophisticated technological procedures are being implemented. To maintain the competitiveness and diversification of the production and to expand to the other markets, it is necessary to monitor the technological development.

In the case of concasting, it is not possible to fulfil these requirements without the application of the models of caster processes depending on thermo-mechanical relationships. These models can be applied both off-line and on-line. For an off-line model the calculation time is longer than the actual casting process. An on-line model runs in real time and uses the data directly from the operation - and the time used for the calculation is equal or shorter than the time of the actual process.

These models support the designs of new machines and the redesigns of old machines. They facilitate the identification and quantification of any potential defect and the optimization of various operational conditions with the aim to increase the productivity and minimize the occurrence of defects ${ }^{1}$.
Due to the complexity of the investigations of the influences of all the involved factors, it is not possible to develop a mathematical model that would cover all of them. It is better to group the influences according to the three main parameters, the heat and the mass transfer and the mechanical behaviour.

The influences of the heat and the mass transfer are the greatest because the temperature field gives rise to mechanical and structural effects. The development of a model of the temperature field (of a slab) with an interface providing the data for the mechanical stress and strain models is therefore the top-priority task.

The new caster for casting steel must be designed to cast different types of steel, including special types, with the maximum quality. Figure $\mathbf{1}$ shows a diagram of a modern caster with a straight first section, followed by a curvature. In segments 1 to 12 the displacement of the whole structure and of individual rollers with a small radius can be controlled hydraulically. Another trend in the modern caster is a split of the secondary-cooling area into several zones, in this case up to 17 individually controlled cooling zones equipped with air-mist nozzles. More information about the optimization of the secondary cooling is found in ${ }^{2,3}$. 


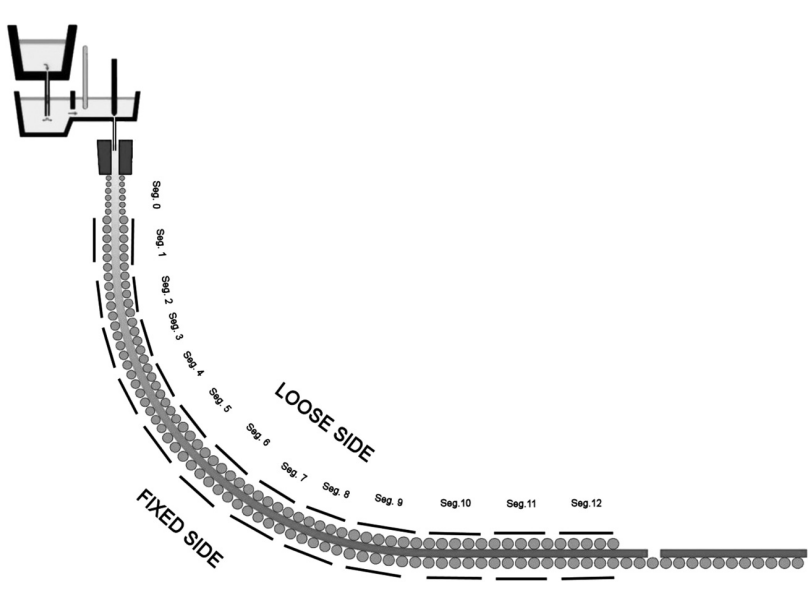

Figure 1: Slab caster

Slika 1: Naprava za ulivanje slabov

In continuous casting of steel there are two problems that affect the quality of the resulting slabs. The first is the contraction of steel during its cooling in the caster; to prevent internal shrinkage the rollers that are in contact with the blank must be set to reduce the profiles of individual segments. A fixed reduction is optimal only for one temperature profile of one blank, but a change in the casting speed makes the reduction larger or smaller. The second problem is bulging, i.e., the bulge of a solidified shell due to the hydrostatic pressure of the steel. This bulge requires additional rollers and thus leads to the alternating stress, decreasing the possibility of cracking. The solution of both problems is soft reduction (Figure 2). On one side of the roller track, the caster from Figure 1 usually has a small radius with options in real time to adjust the positions of the rollers and, thereby, control the reduction profile. The reduction can be carried out only in the place where the centre of the slab is still stiff and the optimum point is the end of the solidification (the metallurgical length). This paper aims to find out when it is necessary to use soft reduction during steel casting and when it is desirable to have linear or other profiles. To answer these questions a model of the temperature field ${ }^{4}$ is applied.

\section{MODEL OF THE SLAB TEMPERATURE FIELD}

The 3D model was first designed as an off-line version and later as an on-line version so that it worked in real time. After being corrected and tested and thanks to the universal nature of the code, it is possible to implement it on any caster. The numerical model takes into account the temperature field of the entire slab (from the meniscus of the level of the melt in the mould to the cutting torch) using a 3D mesh containing more than a million nodal points.

The solidification and cooling of a concast slab are global problems of the 3D transient-heat and mass transfer. If the heat conduction within the heat transfer in this

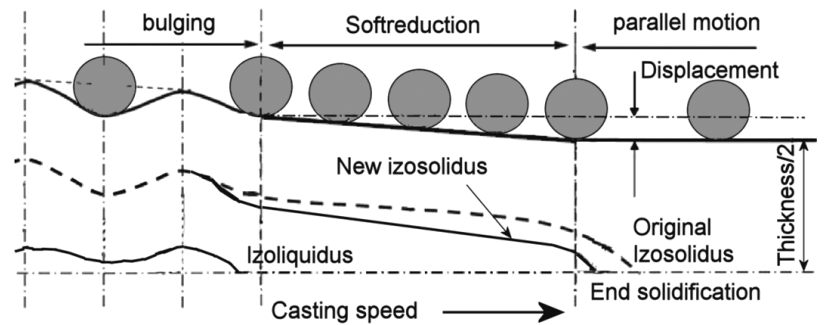

Figure 2: Diagram of soft reduction Slika 2: Shematski prikaz mehke redukcije

system is decisive, the process is described with the Fourier-Kirchhoff equation. It describes the temperature field of a solidifying slab in all three states: at the temperatures above the liquidus (i.e., the melt), within the interval between the liquidus and solidus (i.e., in the mushy zone) and at the temperatures below the solidus (i.e., the solid state). For reliable solutions it is appropriate to use the explicit numerical method of control volumes. A numerical simulation of the release of the latent heats of the phase or structural changes is carried out by introducing the enthalpy function dependent on temperature $T$, preferably in the form of the enthalpy related to unit volume $H_{v}$, containing the latent heats. After an automated generation of the mesh (pre-processing), the model uses the thermophysical material properties of the investigated system, including their dependence on the temperature - in the form of tables or using polynomials: heat conductivity $k$, specific heat capacity $c$ and density $\rho$ of the cast metal. The temperature distribution in the slabs is described with the enthalpy balance equation.

A simplified Equation (1), suitable for application on radial casters with a large radius, where only the speed

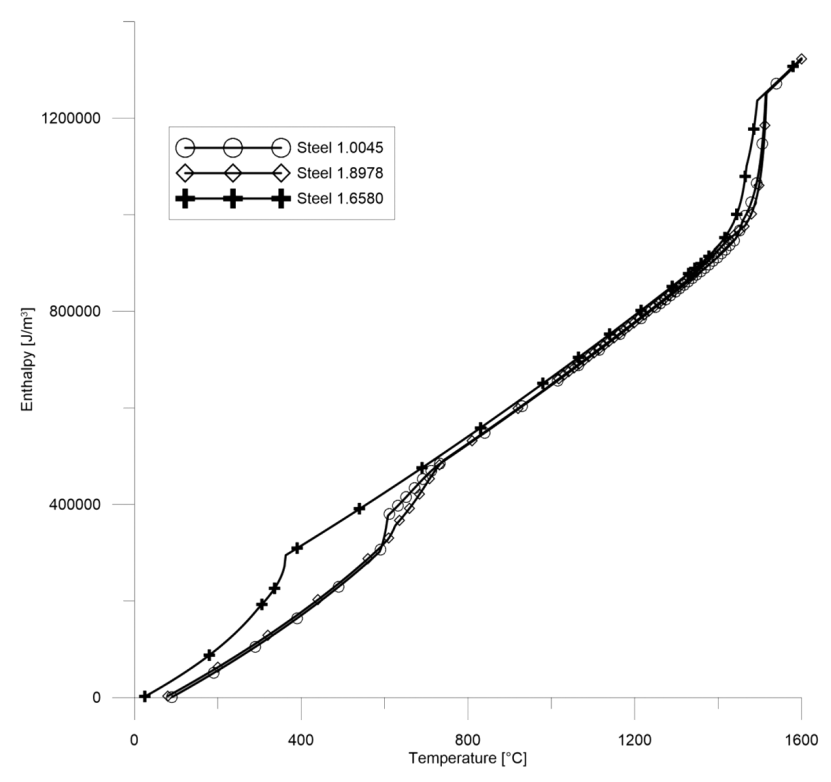

Figure 3: Enthalpy functions of steels

Slika 3: Funkcija entalpij jekel 
Table 1: Selected types of steel with their compositions used for the calculation Tabela 1: Kemijska sestava izbranih jekel, uporabljenih pri izračunu

\begin{tabular}{|c|c|c|c|c|c|c|c|c|c|c|c|c|c|c|c|c|c|}
\hline Class & Mark & Group & $\mathrm{C}$ & $\mathrm{Mn}$ & $\mathrm{Si}$ & $\mathrm{P}$ & $\mathrm{S}$ & $\mathrm{Cu}$ & $\mathrm{Ni}$ & $\mathrm{Cr}$ & $\mathrm{Mo}$ & $\mathrm{V}$ & $\mathrm{Ti}$ & $\mathrm{Al}$ & $\mathrm{Nb}$ & $T_{\text {solidus }}$ & $T_{\text {liquidus }}$ \\
\hline 1.0045 & S355G8 & 1 & 0.011 & 1.550 & 0.450 & 0.075 & 0.025 & 0.000 & 0.000 & 0.000 & 0.00 & 0.000 & 0.000 & 0.375 & 0.020 & 1443.6 & 1514.1 \\
\hline 1.8978 & L555MB & 2 & 0.050 & 1.600 & 0.300 & 0.150 & 0.010 & 0.250 & 0.150 & 0.250 & 0.000 & 0.000 & 0.015 & 0.350 & 0.055 & 1466.0 & 1516.4 \\
\hline 1.6580 & 30CRNIMO & 3 & 0.280 & 0.450 & 0.250 & 0.125 & 0.025 & 0.100 & 1.900 & 1.900 & 0.350 & 0.000 & 0.000 & 0.300 & 0.000 & 1371.5 & 1493.8 \\
\hline
\end{tabular}

(of the movement of the slab) component $w$ in the $z$-direction is considered, is:

$$
\frac{\partial H_{\mathrm{v}}}{\partial t}+\frac{\partial}{\partial z}\left(\rho w_{z} H_{\mathrm{v}}\right)=k\left(\frac{\partial^{2} T}{\partial x^{2}}+\frac{\partial^{2} T}{\partial y^{2}}+\frac{\partial^{2} T}{\partial z^{2}}\right)
$$

Volume enthalpy $H_{\mathrm{v}}$ as a thermodynamic function of the temperature must be known for each specific steel. It depends on the steel composition and the cooling rate. The dependence of function $H_{\mathrm{v}}$ for three different steels is shown in Figure 3.

The unknown enthalpy of the general nodal point of the slab in the next time step $(\tau+\Delta \tau)$ is expressed with the following explicit formula:

$$
\begin{aligned}
& H_{\mathrm{v}_{i, j, k}}^{(\tau+\Delta \tau)}=H_{\mathrm{v}_{i, j, k}}^{(\tau)}+\left(Q z 1_{i, j}+Q z_{i, j}+Q y 1_{i}+Q y_{i}+\right. \\
& +Q x 1+Q x) \cdot \frac{\Delta \tau}{\Delta x \cdot \Delta y \cdot \Delta z}
\end{aligned}
$$

The heat flow through the general nodal point $(i, j, k)$ in the $z$-direction is described with Equation (3):

$$
Q z_{i, j}=k \frac{A_{z}}{\Delta z}\left(T_{i, j, k+1}^{(\tau)}-T_{i, j, k}^{(\tau)}\right)-A_{z} w_{z} H_{\mathrm{v}_{i, j, k}^{(\tau)}}^{(\tau)}
$$

The initial condition for the solution is the setting of the initial temperature in individual points of the mesh. The appropriate value is the highest possible temperature, i.e., the casting temperature. The boundary conditions in different places and different systems are described with Equations (4a) to (4e):

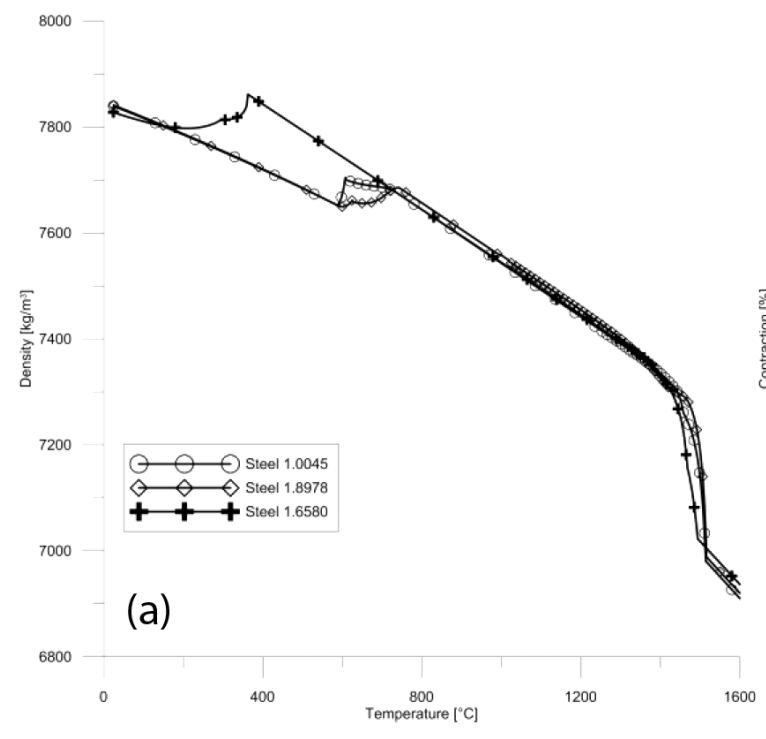

Figure 4: a) Density and b) contraction of the selected steels Slika 4: a) Gostota in b) krčenje izbranih jekel
1. $T=T_{\text {cast }}$ at the meniscus

2. $-k \frac{\partial T}{\partial n}=0$ at the plane of symmetry

3. $-k \frac{\partial T}{\partial n}=a-b \sqrt{\frac{L_{\text {mould }}}{w_{z}}}$ in the mould

4. $-k \frac{\partial T}{\partial n}=\left[h_{\mathrm{tc}}+\sigma_{0} \varepsilon\left(T_{\text {surface }}^{2}+T_{\mathrm{amb}}^{2}\right)\left(T_{\text {surface }}+T_{\text {amb }}\right)\right]$.

( $\left(T_{\text {surface }}-T_{\text {amb }}\right)$ in the secondary- and tertiary-cooling zones

5. $-k \frac{\partial T}{\partial n}=11513.7 T_{\text {surface }}^{0.76} w_{z}^{-0.2}(2 \theta)^{-0.16}$ beneath the

support rollers ${ }^{5}$.

\section{PARAMETRIC STUDY OF SLAB CASTING}

For this parametric study we selected three steels with different chemical compositions, where the problems of internal defects ${ }^{4}$ were solved. The chemical compositions are shown in Table 1, which also shows the liquidus and solidus temperatures.

Solidification-analysis package IDS using the chemical compositions for calculating the thermophysical properties is used to model the temperature field. ${ }^{6}$ As can be seen from Figure 4 the density in the temperature range between the liquidus temperature and $800{ }^{\circ} \mathrm{C}$ is almost identical for all three investigated steel grades.

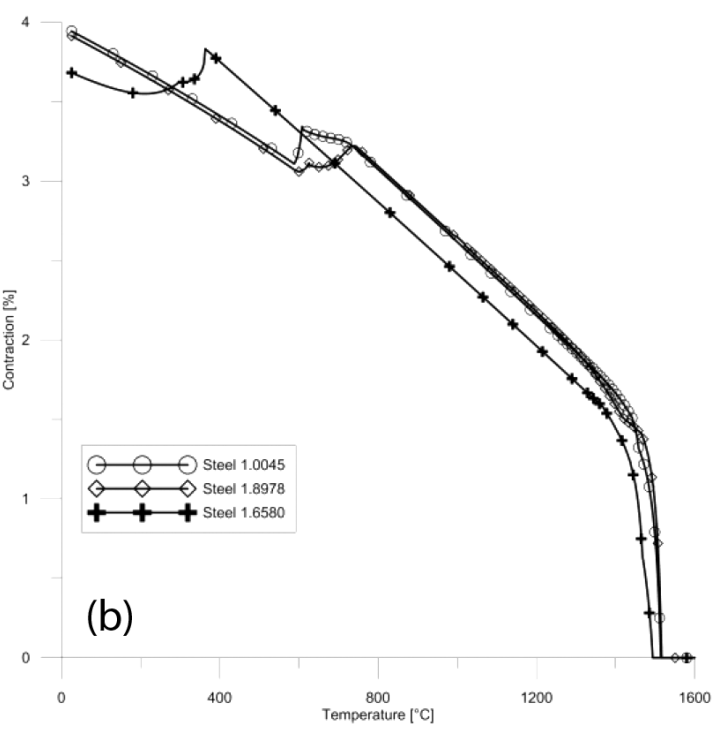



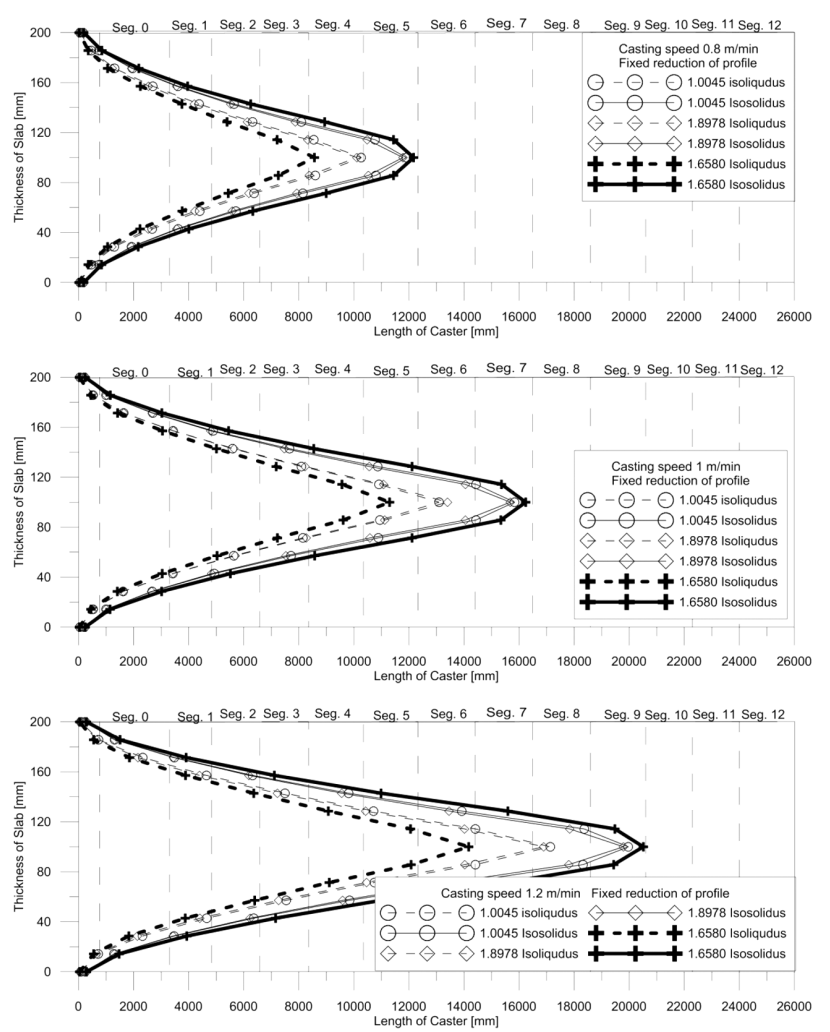

Figure 5: Liquidus and solidus temperatures for casting speeds of $(0.8,1.0$ and 1.2$) \mathrm{m} / \mathrm{min}$

Slika 5: Likvidusna in solidusna temperatura za hitrosti ulivanja $(0,8$, $1,0$ in 1,2$) \mathrm{m} / \mathrm{min}$

An analogous conclusion can be made for the contraction (Figure 4). However, the cross-sectional reduction of a cast blank has to be considered for the temperatures lower than $800{ }^{\circ} \mathrm{C}$, together with the influence of the structural-phase changes in the solid state. In such cases, the casting control has to take into account the cross-sectional reduction due to the phase changes, or the secondary-cooling requirements, to be properly updated to keep the temperature of the blank above $800{ }^{\circ} \mathrm{C}$.

The next step is a parametric study of the simulations of casting the three steel classes and three casting speeds $((0.8,1.0$ and 1.2$) \mathrm{m} / \mathrm{min})$, representing the expected caster operating range. The calculated waveforms of the isolines of the liquidus and solidus are shown in Figure 5.

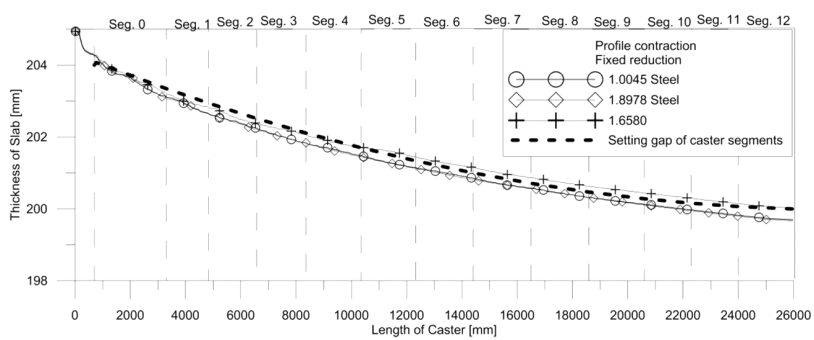

Figure 6: Contraction due to the thickness and slab-temperature decreases and the setting of the roll gap

Slika 6: Profil krčenja zaradi zmanjšanja debeline in temperature slaba ter nastavitev reže med valji

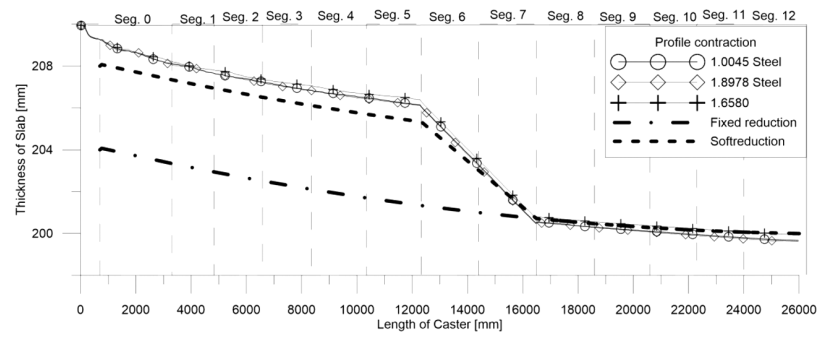

Figure 7: Contraction profile that uses soft reduction in segments 6 and 7

Slika 7: Profil krčenja pri uporabi mehke redukcije v segmentih 6 in 7

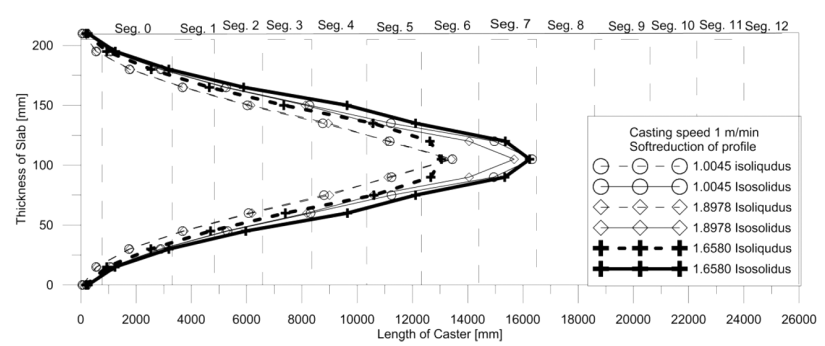

Figure 8: Course liquidus and solidus isolines when applying soft reduction in segments 6 and 7

Slika 8: Likvidusne in solidusne izolinije pri uporabi mehke redukcije v segmentih 6 in 7

These calculations and other parameters, such as the temperature superheat, the primary and secondary cooling, are set in equal forms. A constant reduction of the profile is considered, so the resulting slab thickness is $200 \mathrm{~mm}$ (Figure 6).

Figures 6 and 7 show the calculated contraction profiles for the selected classes of steel. In both cases the calculation considered is calculated for a casting speed of $1 \mathrm{~m} / \mathrm{min}$ and the conditions corresponding to Figure 5 as the basic requirements for the output profile on the machine and a slab thickness of about $200 \mathrm{~mm}$. The thick dashed line marks the roller positions obtained with the narrowing of the machine profile. To allow the use of soft reduction the input size of a blank must be larger. The difference in the size of the mould is $205 \mathrm{~mm}$ for the caster without soft reduction and $210 \mathrm{~mm}$ for the caster with soft reduction.

The temperature field in the form of mileage isocurves of the liquidus and solidus considering soft reduction is shown in Figure 8. With respect to the position of the isolines of the solidus and liquidus temperature, the temperature field is virtually the same, as shown in the middle of Figure 5. However, it should be understood that the initial thickness of the slab is larger by $5 \mathrm{~mm}$ because soft reduction shortens the metallurgy length.

\section{CONCLUSION}

This paper presents a 3D numerical model of a temperature field (for concasting steel) using the in-house software and its applications for the initial study that compares the waveforms of liquidus and solidus isolines 
and strand shrinkage. Furthermore, we compared a caster with a constant constriction, i.e., with a fixed adjustment between the roller gap and the caster with adjustable rollers used for controlling the narrowing, i.e., soft reduction. The results of this analysis will be used in a mathematical model designed for the management of soft reduction. The mathematical model will be integrated in the control systems at all the levels within the automation pyramid that is being developed in the ASM Automation Company (www.asmautomation.com). One of the future tasks is a study of the stochastic behaviour of the continuous casting process ${ }^{7}$.

\section{Acknowledgments}

This work is a result of the research and scientific activities of the NETME Centre, the regional R\&D centre built with the financial support from the Operational Programme Research and Development for Innovations within a NETME Centre project (New Technologies for Mechanical Engineering), Reg. No. CZ.1.05/2.1.00/01. 002 and, in the follow-up sustainability stage, supported through NETME CENTRE PLUS (LO1202) with the financial means from the Ministry of Education, Youth and Sports of the Czech Republic under the National Sustainability Programme I.

\author{
Nomenclature \\ a constant of the mold $\left(\mathrm{W} / \mathrm{m}^{2}\right)$ \\ $A$ area $\left(\mathrm{m}^{2}\right)$ \\ $b$ constant of the mold $\left(\mathrm{W} /\left(\mathrm{m}^{2} \mathrm{~s}^{0.5}\right)\right)$ \\ $c$ specific heat capacity $(\mathrm{J} /(\mathrm{kg} \mathrm{K}))$ \\ $h_{\mathrm{tc}}$ heat-transfer coefficient $\left(\mathrm{W} /\left(\mathrm{m}^{2} \mathrm{~K}\right)\right)$ \\ $H_{v}$ volume enthalpy $\left(\mathrm{J} / \mathrm{m}^{3}\right)$
}

$k$ heat conductivity $(\mathrm{W} /(\mathrm{m} \mathrm{K}))$

$L_{\text {mould }}$ length of the mould (m)

$T$ temperature (K)

$T_{\text {amb }}$ ambient temperature $\left({ }^{\circ} \mathrm{C}, \mathrm{K}\right)$

$T_{\text {cast }}$ casting temperature $\left({ }^{\circ} \mathrm{C}, \mathrm{K}\right)$

$T_{\text {surface }}$ temperature of the surface $\left({ }^{\circ} \mathrm{C}, \mathrm{K}\right)$

$q$ density of the heat flow $\left(\mathrm{W} / \mathrm{m}^{2}\right)$

$Q x, Q y, Q z$ heat flows (W)

$x, y, z$ axes in a given direction (m)

$w_{z}$ casting speed in a given direction $(\mathrm{m} / \mathrm{s})$

$\rho$ density $\left(\mathrm{kg} / \mathrm{m}^{3}\right)$

$\sigma_{\mathrm{o}}$ Stefan-Bolzmann constant $\left(\mathrm{W} /\left(\mathrm{m}^{2} \mathrm{~K}^{4}\right)\right)$

$\varepsilon$ emissivity (-)

$\Theta$ angle of the contact $\left(^{\circ}\right)$

$\tau$ time (s)

\section{REFERENCES}

${ }^{1}$ A. W. Cramb (Ed.), The Making, Shaping and Treating of Steel: Casting Volume, 11th edition, The AISE Steel Foundation, Pittsburgh, PA, USA 2003, 1000

${ }^{2}$ T. Mauder, C. Sandera, J. Stetina, Mater. Tehnol., 46 (2012) 4, 325-328

${ }^{3}$ J. Stetina, T. Mauder, L. Klimes, F. Kavicka, Mater. Tehnol., 47 (2013) 3, 311-316

${ }^{4}$ J. K. Brimacombe, The Challenge of Quality in Continuous Casting Process, Metallurgical and Materials Trans. B, 30 (1999), 553-566, doi:10.1007/s11663-999-0016-7

${ }^{5}$ J. Zhang, D. Chen, S. Wang, M. Long, Compensation control model of superheat and cooling temperature for secondary cooling of continuous casting, Steel Research Int., 82 (2011) 3, 213-221 doi:10.1002/srin.201000148

${ }^{6}$ J. Miettinen, S. Louhenkilpi, J. Laine, Solidification analysis package IDS, Proceeding of General COST 512 Workshop on Modelling in Materials Science and Processing, ECSC-EC-EAEC, Brussels, Luxembourg, 1996

${ }^{7}$ E. Zampachova, P. Popela, M. Mrazek, Optimum beam design via stochastic programming, Kybernetika, 46 (2010) 3, 571-582 